\title{
波浪推算モデルによる低波浪時の 有義波推算精度を低下させる要因の検討
}

\author{
琴浦 毅 1 ・田中 仁 2 \\ 1 正会員 五洋建設 (株) 技術研究所 \\ ( ( 329-2746 栃木県那須塩原市四区町 1534-1) \\ E-mail: Tsuyoshi.Kotoura@mail.penta-ocean.co.jp \\ 2 フェロー会員 東北大学大学院教授 工学研究科土木工学専攻 \\ ( T 980-8579 宮城県仙台市青葉区荒巻字青葉 6-6-06) \\ E-mail: hitoshi.tanaka.b7@tohoku.ac.jp
}

\begin{abstract}
第三世代波浪推算モデルである WAM は設計波の算定，波浪予測情報の提供など実務に適用されている ものの, 海上工事が可能である低波浪時における予測精度の検証は少ないため, 著者らはこれまでWAM を海上工事に適用するための検証を進めてきた .これらの検討を通じて，特に低波浪時において波高を過 大評価，周期を過小評価するケースがあることを確認していた .

本研究では低波浪時の波浪推算精度を低下させる要因を現地観測との比較を通じ検討した。光の結果， 周波数スペクトルを用いた比較検証から，WAM においては高周波数成分のエネルギーを過大に評価する 場合があることを確認した . 全体エネルギーが小さい低波浪時においては，過大評価したエネルギーが相 対的に大きく，結果的に波高の過大評価，周期の過小評価につながっていると考えられ，この高周波数成 分のエネルギーの評価改善が低波浪時の予測精度向上につながると推察した 。
\end{abstract}

Key Words : Wave prediction accuracy, WAM model, Marine works, Observation

\section{1. はじめに}

建設工事においては風雨などの気象情報の入手は工 程管理, 安全管理上重要であるが, 海上工事においては 波 潮流という海象要因も加わることとなる .㫕のため,

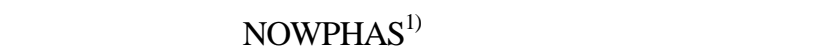
化された波浪予報情報 ${ }^{2)}$ を得ながら，これまでの経験を 踏まえ作業の可否判断を行ってきた . しかし, 海上工事 では, 工事により船船が大型の場合や, 船団の数が多い 場合などは, 使用船舶の移動, 離脱に多くの時間が必要 となる .弚のため 海象条件の悪化が予想される場合は， 時間的な余裕を持ってあらかじめ現場海域から待避する ことが多い．この場合，使用船舶の待避を半日以上前に 判断することもあり，精度の高い波浪予測情報が得られ るのであれば，効率的な待避か河能となり，工程管理， 安全管理上, 非常に有効になると考えられる.しかし， 波浪推算モデルに関して施工可否判断への適用に着目し ている事例は少なく，また，低波浪時の予測精度低下要 因について検討した事例は少ない．

著者らはこれまでも海上工事施工限界波高を $1 \mathrm{~m}$ 程度 として ,いくつかの地点において波浪推算モデルの精度 検証を行ってきた ${ }^{3) \sim の) . ~}$ 乥の結果, 波浪推算モデルは施
工可否判断に活用できる精度を有していることを確忍し ているものの，低波浪時期に波高を過大評価，周期を過 小評価する事例があることを確認している．

乥こで, 本研究では施工可否判断海象条件 (波高 $1.0 \mathrm{~m}$ 程度) を対象として, 直江津港, 鹿島港で実施した現地 観測結果と波浪推算モデルの予測結果の比較を通じて， 低波浪時の波浪推算モデルの予測精度低下発生要因につ いて検討した .

\section{2. 現地観測}

\section{(1) 直江津港}

新潟県上越市直江津港において海底設置型波高計によ り観測した7) 観測期間は2009年12月9日 2010年1月8日で あり，水深 $25 \mathrm{~m} て 0.5 \mathrm{~s}$ の連続観測を実施した . 表-1は観測 条件, 図-1は設置位置である。図-2は言の時に観測され た有義波高，有義波周期の時系列を示しており，最大で 有義波高 $5 \mathrm{~m}$ 前後の高波浪が来襲するなと静穏な海象は 少なく，海洋工事の施工可否判断波高を $1.0 \mathrm{~m}$ 設定する と, 海上工事か可能となる日は非常に少ない。有義波周 期は高波浪時には10秒程度となっているが，今回の対象 
とする波高 $1 \mathrm{~m}$ 程度では5，6秒程度となっている．

(2) 鹿島港

茨城県鹿島港の観測期間は2015年6月15日 7月8日で あり，水深 $20 \mathrm{~m} て 0.5 \mathrm{~s} の$ 連続観測を実施した . 表-1は観測 条件 , 図-1は設置位置である。図-2はNOWPHASて観測 された同時期の有義波高，有義波周期の時系列を示して おり , この期間は有義波高が $1.0 \mathrm{~m}$ 程度の海象条件が多く， その時の有義波周期は8秒〜12秒程度になっている。

なお，本研究における現地観測位置は南防波堤からの 距離が $100 \mathrm{~m}$ 程度なので, 防波堤からの反射の影響も含ま れていると考えられる.しかし，概ね1波長程度以上は離 れていることを考慮すると位相干渉の影響は小さく，防 波堤の反射率を考慮することで入射波エネルギーを推定 することは可能であると考えられる .

表-1 現地観測緒元

\begin{tabular}{c|c|c}
\hline 項目 & 直江津港 & 鹿島港 \\
\hline 観測期間 & 2009 年 12 月 & 2015 年 6月 \\
\hline 水深 & $25 \mathrm{~m}$ & $20 \mathrm{~m}$ \\
\hline 観測モード & \multicolumn{2}{|c}{20 分連続観測 } \\
\hline サンプリング間隔 & \multicolumn{2}{|c}{$0.5 \mathrm{~s}$} \\
\hline 観測成分 & 4 成分 (水位 , 水圧 , 流速 $(\mathrm{U}, \mathrm{V}))$ \\
\hline
\end{tabular}
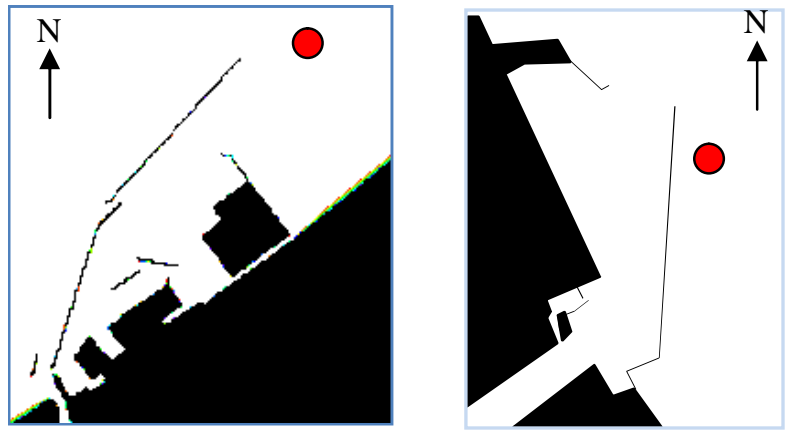

図-1 観測位置図 (左 : 直江津港, 右 : 鹿島港)
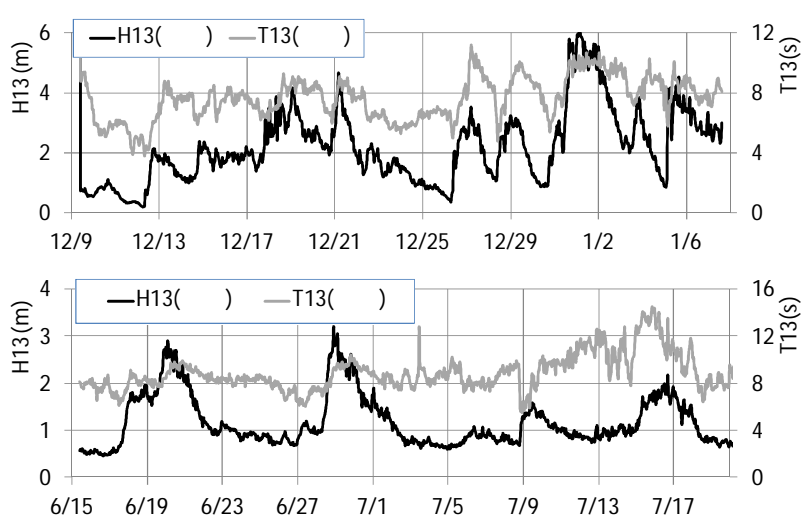

図-2 観測時系列（上 : 直江津港，下：鹿島港)

\section{3. 波浪推算モデル}

波浪推算モデルは太平洋域を図-3 に示す領域の計算 を行い, 図-4 に示す領域に接続した . 図-3 の太平洋領 域では $0.5^{\circ}$ 格子の気象庁 GPV (GSMgl)，図-4 の領域 では約 20km 格子の気象庁 GPV (GSMjp) 海上風データ を約 $10 \mathrm{~km}$ 格子に線形補間し，WAM モデルへの入力条 件とした .なお，WAM の最小周波数は $0.0418 \mathrm{~Hz}$ として いるが, 高周波数側の影響を評価するために川口ら ${ }^{8)}$ 参考に最大周波数を $1.174 \mathrm{~Hz}$ とした (表-2) .

ここで, WAM は深海モデルとしているため, 波長水 深比が小くなるケースでは実測值との承離力発生する ことが予想される . 著者らはWAM の精度検証を太平洋 側で実施した時に ,NOWPHAS の沿岸波高計と比較をす る場合，エネルギ一平衡方程式を用いて，海岸地形，海 底地形の影響を考慮するモデルを組み合わせることで， 検証を実施している ${ }^{4)}$ 。

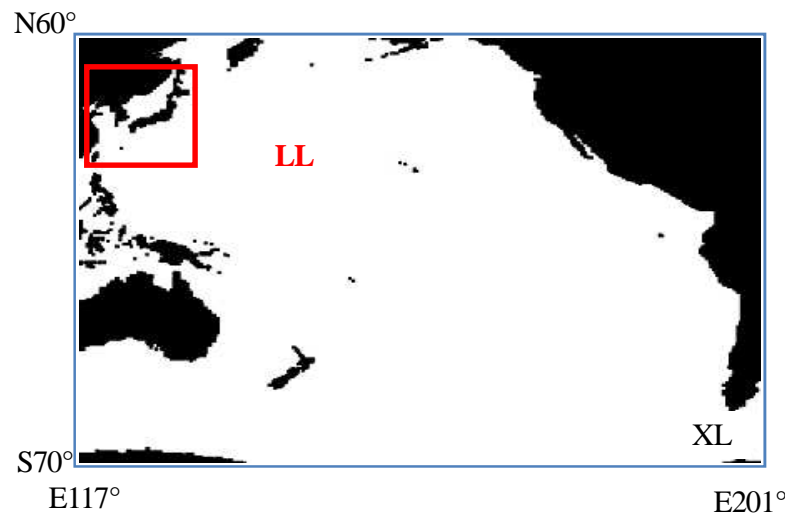

図-3 太平洋言算領域図 $\left(0.5^{\circ}\right.$ 格子 : 領域 XL)

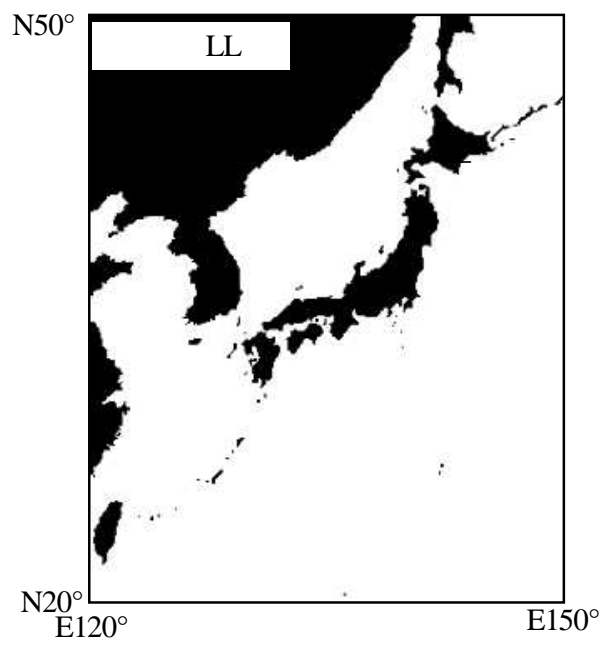

図-4 計算領域図(10km 格子 : 領域 LL) 
表- 2 WAM 計算諸元

\begin{tabular}{c|c|c}
\hline 領域番号 & $\mathrm{LL}$ & $\mathrm{XL}$ \\
\hline 計算領域 (北緯) & $20^{\circ} \sim 50^{\circ}$ & $-70^{\circ} \sim 60^{\circ}$ \\
\hline 計算領域 (東経) & $120^{\circ} \sim 150^{\circ}$ & $117^{\circ} \sim 295^{\circ}$ \\
\hline 最小周波数 & \multicolumn{2}{|c}{$0.042 \mathrm{~Hz} \sim 1.174 \mathrm{~Hz}$} \\
\hline 周波数分嗐㥪 & \multicolumn{2}{|c}{35} \\
\hline 周波数間隔 & \multicolumn{2}{|c}{ 倍率 1.1} \\
\hline 方向分嗐数 & \multicolumn{2}{|c}{16} \\
\hline 水深条件 & \multicolumn{2}{|c}{ 深海 } \\
\hline 空間間隔 & $0.1^{\circ}$ & $0.5^{\circ}$ \\
\hline 伝播計算時間刻み & $300 \mathrm{~s}$ & $900 \mathrm{~s}$ \\
\hline 風使用データ & $\mathrm{GSMjp}$ & $\mathrm{GSMgl}$ \\
\hline 風データ時間間融 & \multicolumn{2}{|c}{$3600 \mathrm{~s}$} \\
\hline
\end{tabular}

今回の観測においては直江津の波長は $56 \mathrm{~m}$ 程度 (水深 $25 \mathrm{~m}$, 周期 6 秒) であるため, 水深波長比は 0.45 程度と なる.したがって, 海岸線に対して $50^{\circ}$ 以上の角度を持 って入射する場合は波向きが多少変化していると考えら れるが, 16 方位で分割した場合には影響がないと考えら れる。

また , 鹿島港の波長水深比は 0.22 程度となり，沖入射 角度が $50^{\circ}, 70^{\circ}$ の場合，観測水深位置では $43^{\circ}, 53^{\circ}$ 程度となるため 波向きによっては 16 方位分割において 波向きか変化する可能性はあるが, 卓越波向きがESEで あることを考慮すると影響は小さいと推察される．

ただし，不規則に含まれる有義波周期よりも低周波数 側のエネルギーについては必ずしも影響がさいとはい えない可能性がある. 弚のあたりの検証も含めて, 施工 可否判断の波高 $1 \mathrm{~m}$ 付近を対象とした本検討においては 海底地形を考慮しない深海タイプのWAM を用いること とした .

\section{4. 波浪推算モデルの推算精度低下要因の検 証}

\section{(1) 直江津港}

図- 5 は直江津港の観測値と波浪推算值の時系列であ る. 波高の時系列は波高 $1.0 \mathrm{~m}$ 以下の静稳な海象条件に おいてもWAM の再現性は良い，光の一方で，WAM は 周期については高波浪期間で 1 秒程度 , 静湬期間では 2 秒程度過小評価している．この要因を検証するために， 高波浪として 12 月 19 日 0 時, 低波浪として 12 月 25 日 17 時, 22 時の周波数スペクトルについて, 現地観測と波 浪推算の比較を図 6 に示した .

高波浪時は, スペクトルのピークか高周波側に少しシ フトしていることや, WAM 最小周波数 : $0.0418 \mathrm{~Hz}$ 以下 を評価できないことが周期を過小評価する要因になって

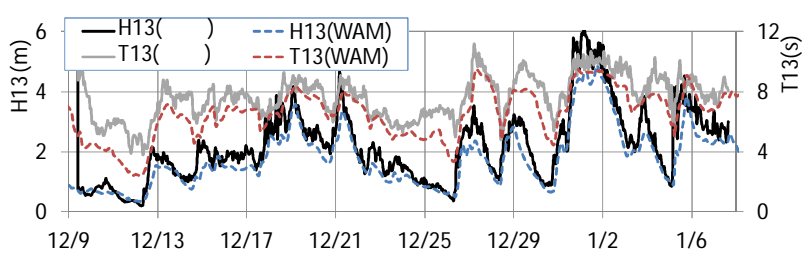

图- 5 観測データとWAM の時系列 (直江津)
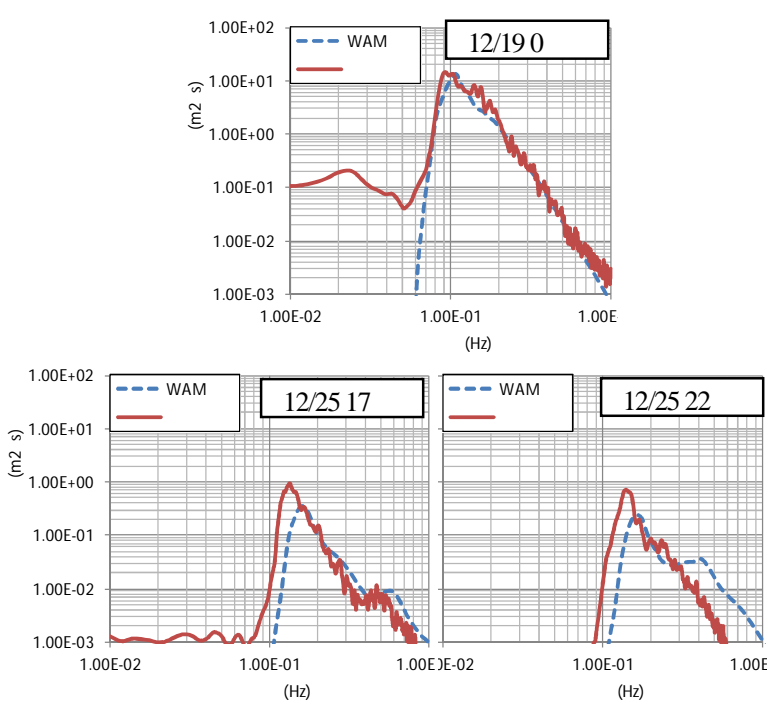

図-6 周波数スペクトルの比較(直江津)

いると考えられるが, 高低周波数のスペクトル形状やエ ネルギーについても良く対応しており，高波浪時におけ るWAM の推算精度の高さはあらためて確忍されたとい える .

低波浪時は, 観測の 17 時, 22 時ともに $0.14 \mathrm{~Hz}$ 程度が ピークであり, 17 時には $0.47 \mathrm{~Hz}$ にもピークか存在する . しかし, 22 時では $0.47 \mathrm{~Hz}$ のピークが無く, 乥こから $0.14 \mathrm{~Hz}$ 程度のスペクトルピークまでの形状にはほとん ど変化が無い，つまり，現地観測においては, $0.47 \mathrm{~Hz}$ 付 近のエネルギーは 17 時以降に消散したと考えられる .乥 の一方で,WAM では 17 時の時点ではスペクトル形状は 概ね対応しているが，全体的に高周波数側へシフトして いる. また, 22 時の時点でも現地観測では存在していな い $0.4 \mathrm{~Hz}$ 程度にもピークか存在しているなど，観測スペ クトルとは異なり高周波成分を過大評価している .

\section{(2) 鹿島港}

図-7は鹿島港の観測值と波浪推算值の時系列である . 6 月 16 日の波高を $0.3 \mathrm{~m}$ 程度の過大評価, 周期を 2 秒程 度の過小評価している.また， 7 月 13 日頃では現地観 測の周期は増加しているのに対し，波浪推算値では周期 が低下するという逆の結果となっている．

図- 8 は 6 月 16 日 6 時〜 9 時の 1 時間ごとの観測スペ クトルと WAM スペクトルの比較である .この図を見る と, $0.07 \mathrm{~Hz}$ 程度の低周波数側のエネルギーは概ね観測と 


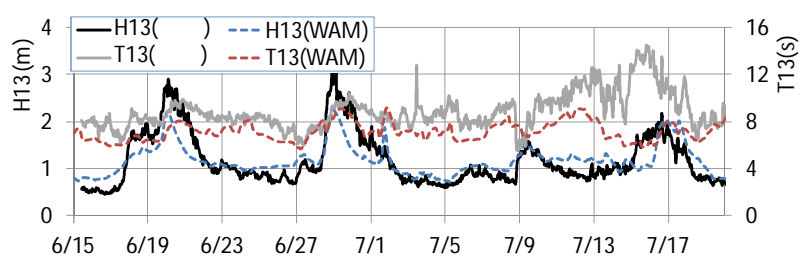

図-7 観測データとWAM の時系列（鹿島）
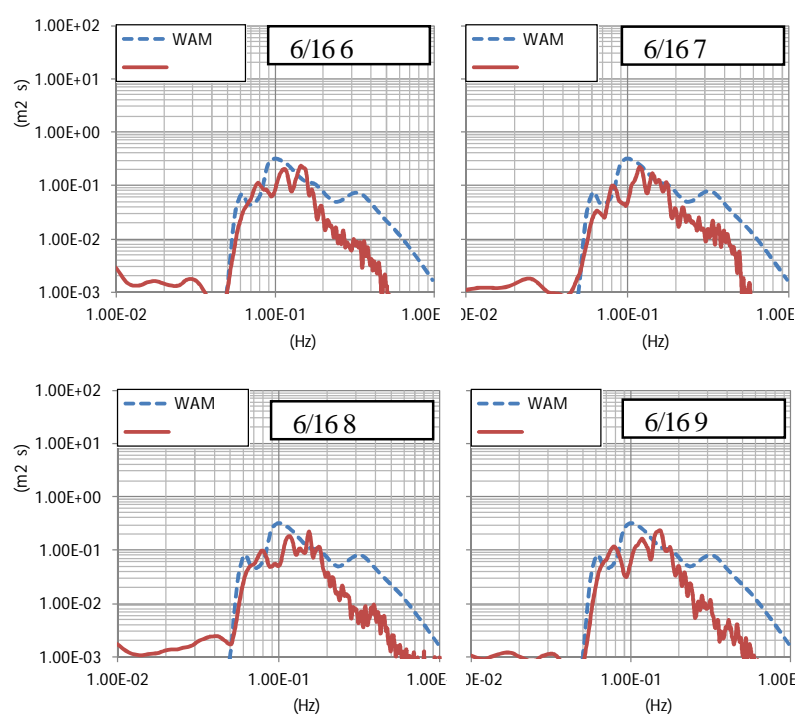

図-8 周波数スペクトル比較 (鹿島港 : 6/16)

WAM て概ね対応していることから，WAM においては うねりの評価は概ねできていると考えられる .これは著 者らの検証で得られた太平洋側の計算領域か広いことに

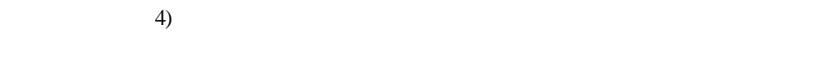
のうねり成分を予測できることは海上工事においては非 常に重要なことである .

兴の一方で, WAM では高周波数側を全体的に過大評 価しており， $0.1 \mathrm{~Hz}$ 付近のピークとは別に $0.3 \mathrm{~Hz}$ 付近に ピークがある . 現地観測では 7 時頃に一時的に $0.3 \mathrm{~Hz}$ 程 度のエネルギーか増大しているが, 兴のエネルギーは 9 時には減少しており，6 時と 9 時のスペクトル形状はほ ほ等しい 、つまり，現地観測においては7 時頃に生じて いる高周波数側のエネルギーが低周波数側に移動して保 持されているわけではなく，消散したと考えられる．し かし，WAM ではエネルギー減少は生じておらず, 高周 波側のエネルギーカ維持されているため，現地観測との 刋離力生じていると考えられる .

台風 1511 号が日本の南海上にいた観測期間後半では 周期がさらに乘離している . 図-9 は台風 1511 号経路図 を示しており，丸の中の文字が日付を示している．つま り, この図は 7 月 7 日〜 7 月 17 日の期間における , 各日 午前 3 時時点の台風 1511 号の中心位置である この経路 図を見ると，日本南海を 7 月 7 日から 7 月 12 日までは西 進し,7月 12 日以降は紀伊半島南側付近を北進している. つまり，台風により発生する南寄りの波の鹿島港への影

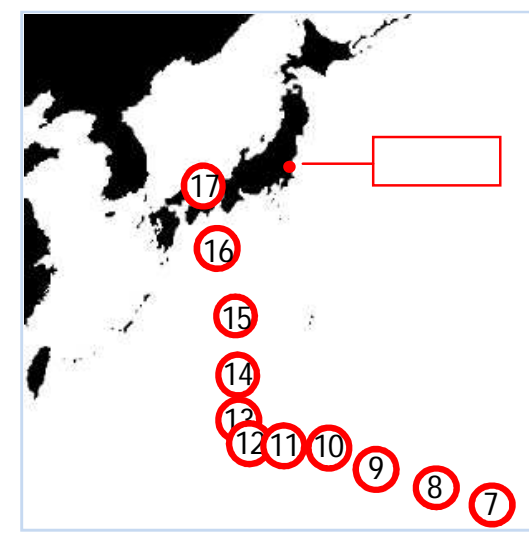

図-9 台風 1511 号経路図 (○内は 7 月の日付)
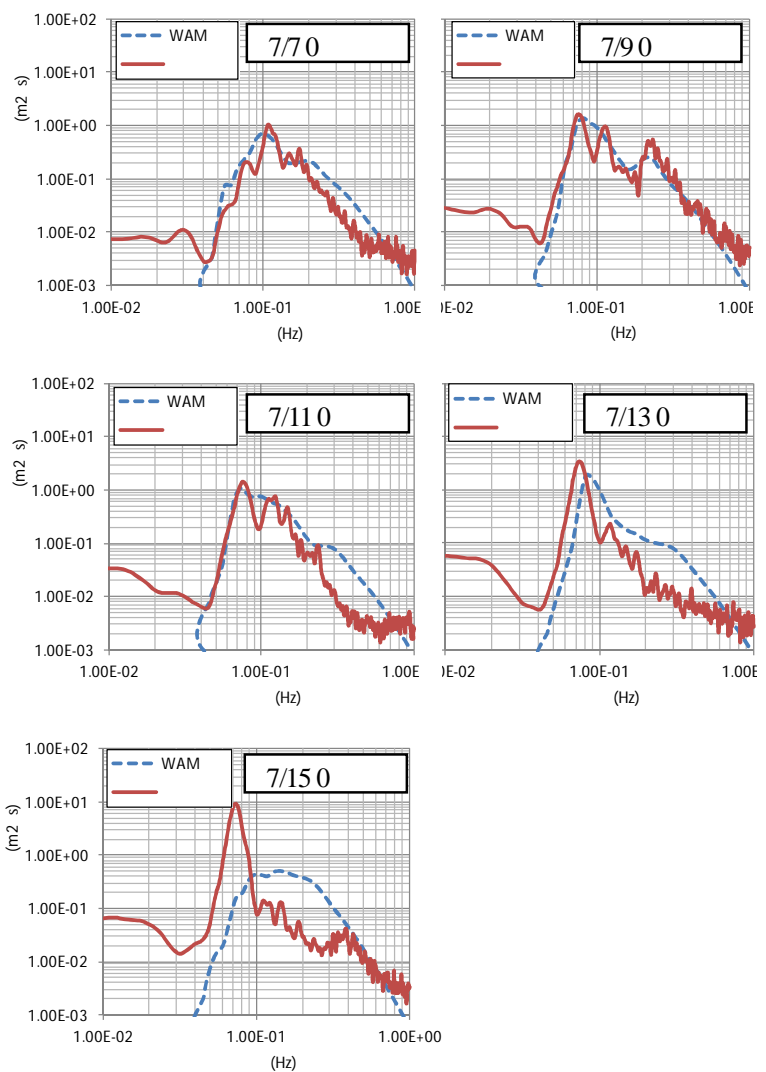

図-10 周波数スペクトルの比較( 鹿島)

響は, 台風の位置により異なり，鹿島港より東側に台風 がある時期は炎の影響は大きく，西側になるにつれて影 響か変化してくることが予想される。

図-10 はこの期間の周波数スペクトルの現地観測と WAM の比較であるが， 7 月 7 日では全体的なスペクト ル形状は対応しており，7 月 9 日では $0.25 \mathrm{~Hz}$ 付近に発生 しているピークについても概ね対応していると考えられ る.しかし，7月 11 日では，低周波数側の精度は良好で あるものの，現地観測は $0.3 \mathrm{~Hz}$ 付近のエネルギーが咸少 しているのに対し，WAM は产の付近のエネルギーが 7 月 9 日と顕著な差はないため過大評価している. 7 月 13 日ではWAMにおいても $0.15 \mathrm{~Hz}$ 付近のエネルギーが咸少 


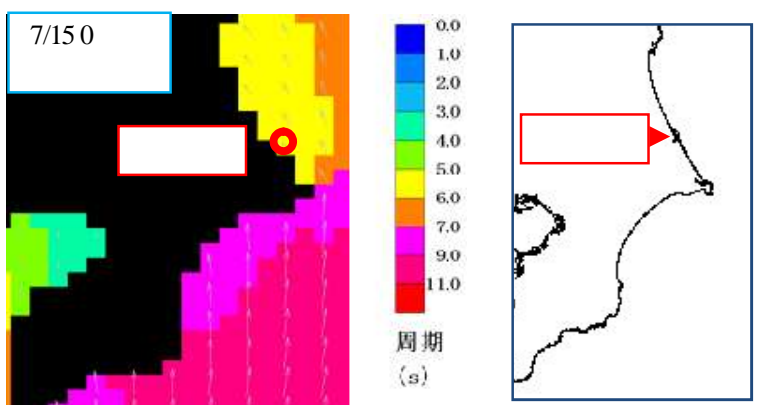

図-11 $7 / 15 \quad 0$ 時の関東周辺の周期分布 , 地形

するなど観測結果と一致する傾向にある一方で， $0.3 \mathrm{~Hz}$ 付近ではWAM は過大評価しているのに加え， $0.08 \mathrm{~Hz}$ 付 近ピークを過小評価している.

7 月 15 日になると WAM ではうねり成分が大幅に低下 しているのに対し，現地観測では高周波数側のみがさら に低下し，低周波数成分のエネルギーは保持されている， この時の台風の位置は紀伊半島の南, 鹿島港とすると南 南西の位置にある .つまり，鹿島港は犬吠崎の遮蔽を受 けることになるため, 犬吠崎付近の地形による屈折 , 回 折の影響が鹿島港では発生しており 現地観測では屈折， 回折の影響を受けやすい低周波成分のエネルギーか維持 されているのに対し，高周波成分のエネルギーが減少し たと考えられる .

図-11は7月 15 日のWAMによる周期分布と地形図で ある、周期分布より犬吠崎の南側では 10 秒程度であるの に対し, 犬吠崎の遮蔽を受ける鹿島港などにおいては周 期が大幅に低下し 6 秒程度になっていることが分かる。 これは，スペクトルからも明らかであるように，低周波 数側の過小評価, 高周波数側の過大評価力影響している．

また , この期間中の NOWPHAS 鹿島の波向きは一律 でESEであった .これは，犬吠崎の遮蔽の影響に加えて， 台風の位置によっては海岸線に平行に入射した $0.08 \mathrm{~Hz}$ 付近のうねり成分が, 海底地形の影響を受けて屈折して いる影響もあると考えられる。

図-11 の周期分布図中の矢印は波向きであるが , 犬吠 崎の背面に回りこむ波か存在しており，WAM の数值拡 散による影響は評価できていると考えられる .しかし， 地形図との比較よりWAM の地形解像度が十分とはいえ ないこと，深海モデルを用いていることか課題であると 示唆される .

\section{(3) 検証結果}

以上の検討より，WAMの推算精度が低下しているいず れのケースにおいても高周波側を過大評価していた .こ の過大評価をしているエネルギーは, 高波浪時のエネル ギーと比較すると相対的にエネルギーが小さいため精度 への影響は小さいと考えられるが, 全体エネルギーが小 さい低波浪時においては, 光の影響は大きく, 精度低下
の要因となっていることか確認された . したがって , 高 周波数側の推算精度の向上を図ることか低波浪時におけ る推算精度向上には重要であるといえる．

第3世代波浪推算モデルでは海上風外力項 $S_{\text {in }}$, 砕波散逸 項 $S_{d s}$,成分波間同士の非線形相互作用 $S_{n}$ の 3 つのソース項 が平衡状態にあることが必要である.

$$
S_{i n}+S_{d s}+S_{n l}=0
$$

ぞして,今回使用したWAMはいずれのソース項もデフ オルトの值を用いているが , このソース項についての改 良を進めることか精度向上になりえることが考えられる すなわち, 海上風から過剩にエネルギーを授与している エネルギ一散逸が不足しているなどが考えられる．

しかし, 直江津の12月25日17時, 鹿島の7月9日0時の高 周波側のスペクトル形状は風による発達を再現しており 今回の現象についてはS 改善する必要はないと判断す る . また , 鹿島の6月16日6時〜9時の検証から，現地では 一時的に発生したエネルギーが $S_{n}$ の効果により低周波数 側一移動することなく，消散していると考えられるため， この現象の予測精度向上には $S_{d s}$ の改善が必要であること が示唆される.

その一方で, 短波重力波領域の検討ではスペクトル形 状力改善を目的として あるが, $S_{n l}$ の役割について重要であることを示している 9).$S_{n l}$ の厳密計算は膨大な時間が必要となるが, 計算時間 短縮を図れる高精度計算手法も提案されており，光の手 法を用いた $S_{n}$ の検証においても， $S_{n}$ の役割の重要性が示 されている(10),11).

本研究ではWAMを海上工事における波浪予測として 用いることが目的であるため，計算時間か非常に重要な 要素となる.したがって, 上記の研究を参考にしつつ精 度向上に向けた取り組みを行い, 実務的に有用な改善に 取り組む必要がある。

\section{5. まとめ}

日本海側，太平洋側の光れ光れの現地観測との比較か ら，WAMは低波浪時に推算精度を低下させる要因は, 高 周波数領域におけるエネルギーの過大評価であることが 確認された．关の一方で，太平洋側の観測との比較から， 低波浪時のうねり成分の推算精度が良好であることか結 果として得られた．つまり，高周波成分の推算精度を向 上させることで, 日本海側はもちろん，太平洋側を含め た日本周辺全域で, うねり成分から高周波成分までスペ クトル形状が一致する予測結果が得られる波浪推算モデ ルとなる．

鹿島港の検討からは地形解像度の不足, 海底地形評価 
の必要性などの課題も示唆された .これらの課題を改善 することで実務的で高性能な波浪推算モデルの開発を進 める予定である .

謝辞 : 本研究を行うにあたり, 九州大学大学院の橋本典 明教授には，WAMモデルを用いた波浪予測について有 益な助言をいただきました．また，波浪予測結果の検証 に利用したNOWPHASデータは国立研究開発法人港湾空 港技術研究所海象情報研究チームのHPより入手させて いただきました .ここに記して関係者に謝意を表します．

\section{参考文献}

1) 川口浩二, 猪股勉, 関克己, 藤木峻 : 全国港湾海洋波浪観 測年報（NOWPHAS 2013），国立研究開発法人＼cjkstart港湾空港 技術研究所

2) 江口一平, 岡田弘三, 中田玩志, 内田洋平, 窪田和彦, 宇都 宮 好博: 沿岸気象海象情報配信システムの高度化 pp.61-66，土木学会論文集 B3 (海洋開発)，2014。

3）森屋陽一, 琴浦毅, 関本恒浩 : 日本海における波浪推算乇 デルを用いた海上・潜水作業可否の予測精度 , 海洋開発論 文集, 第 26 巻, pp.447-452, 2010。

4) 琴浦毅, 森屋陽一, 関本恒浩 : 波浪推算の計算領域力゙海上 作業可否の判定精度に及ぼす影響, 土木学会論文集 B3 (海 洋開発)，Vol.67，No.2，pp.I_880-I_885，2011。

5) 琴浦毅, 森屋陽一, 関本恒浩 : 瀬戶内海における波浪推算
モデルを用いた海上作業可否の判定精度, 土木学会論文集 B3 (海洋開発)，Vol.68 ,No. 2 ,pp.I_959-I_964,2012.

6) 琴浦毅 , 片山裕之 : リーフ地形周辺の海上作業可否に着目 した波浪予測モデルの検討, 土木学会論文集 B3 (海洋開 発)，Vol.71，No.2，pp.I_215-I_220，2015.

7)泉宮尊司，小林雄一，石橋邦彦，関本恒浩，高橋研也， 若松 厚, 石垣 順, 井上俊二, 干渉合成法を用いた 長周期波の伝播・反射特性の解明および水位予測，海 岸工学論文集, 第 66 巻(1), pp. 176-180，2010。

8）川口浩二, 橋本典明, 杉本彰 : 内湾域における波浪推 算精度向上を目的とした第三世代波浪推算モデル WAM の改良, 海岸工学論文集, 第 50 巻,pp.I_191-I_195, 2003 .

9) 橋本典明, 山城賢, 横田雅紀, 児玉充由: 有限新水域 における海洋波の非線形エネルギー輸送に関する検 討，土木学会論文集 B2 (海岸工学)，Vol. 69 ，No. 2 p. I_131-I_135，2013.

10) 田村 仁, 早稲田卓爾，宮澤泰正：風波スペクトルの 平衡領域における非線形相互作用の役割，土木学会論 文集 B2 (海岸工学)，Vol. 69 ，No. 2 p. I_121-I_125， 2013.

11) 田村 仁, William M. DRENNAN, Erik SAHLEE, Hans C GRABER : 短波重力波領域におけるスペクトル形状と ソースバランス, 土木学会論文集 B2 (海岸工学), Vol. 70 , No. 2 p. I_111-I_115 , 2014.

(2016.2.4 受付)

\section{INVESTIGATION ON FACTORS AFFECTING ACCURACY OF WAM PREDICTION UNDER MILD WAVE CLIMATE}

\section{Tsuyoshi KOTOURA and Hitoshi TANAKA}

For maritime constructions, it is highly important to obtain reliable wave predictions for safety operation and work executable judgment. Advanced wave prediction method based on WAM model has recently been utilized in many marine construction sites. However, accuracy of the wave prediction under mild wave climate is not clear. This study investigates accuracy reduction factors of the WAM model based on the comparison between hindcast calculation and field data, with special reference to low wave condition. From this comparison, it is found that spectra obtained from the WAM model gives overestimation at high frequency region $(0.3-0.4 \mathrm{~Hz})$, which might be induced by overestimation of wave height and also by underestimation of wave period in this region. Thus model improvement is required for high-frequency waves in order to increase prediction accuracy for lower waves. 